\title{
Selling research to save it
}

\section{Hanover}

ONLY a year ago, Fredrik Scheller and his group of molecular biologists at the East Berlin Academy of Sciences were content in the knowledge that their biosensor research was as good as anywhere in the world.

But in the newly reunified Germany, Scheller's group - like some 90 per cent of the researchers at the soon-to-bedisbanded academy - is facing imminent unemployment. Knowing that their research is world class is no longer enough. Now they must prove it.

Like a growing number of scientists in what was once East Germany, Scheller is preparing to put together a small company to sell the products of his group's research - and perhaps save some jobs in the process. The group's work on glucosedetecting enzyme membranes is both relatively practical and close to the cutting edge; properly packaged, priced and marketed, it might find buyers in the West.

Come October, ten such groups will test that premise. They are taking the plunge into the hard world of capitalist economics by participating in their first product exposition: the international biotechnology fair Biotechnica 91, to be held in Hanover. At the fair, they will try to sell that small proportion of East German research that is advanced enough and close enough to commercialization to find buyers on a world market.

For most of them, this is virgin territory. The few whose research had commercial application in the year before reunification last year had never had to worry much about world competition; the Soviet Union and the rest of the Eastern Bloc were essentially a captive market. And for the vast majority of the other statesponsored researchers in East Berlin and the rest of East Germany, commercial potential of research was usually a distant concern; their jobs, after all, did not depend on coming up with marketable products. Anyway, without much modern instrumentation and equipment, most of the work was by necessity basic or theoretical - hardly the stuff to spin off blockbuster inventions.

Many of the eastern German researchers who are lucky enough to have some technology that might be marketed have applied to the new Treuhandanstalt agency for help with start-up money for a new company. Set up to sell off the assets of the former eastern state and to help eastern Germans start their own businesses with foreign capital, the Treuhand has the difficult job of deciding what technologies and products might possibly be successful in a Western market.

But the agency has found the going even tougher than expected, as Western investors remain openly sceptical about the marketability of Eastern products. So far it has been able to find buyers for only about five per cent of the old East German companies - the crei.m of the crop - and takers are expected to become even rarer as the pickings get slimmer in the coming year.

Scheller, however, is fortunate enough to be able to bypass the Treuhand morass. $\mathrm{He}$ has found some partners with private capital and is hoping to rent a small laboratory in what, after December this year, will no longer be the academy but will be a smaller research institute that is expected to be called something such as the Research Centre for Biological and Medical Sciences.

There the group hopes to house a few technicians working on producing the enzyme membranes. Not a real research laboratory by any means, but enough to keep producing the materials and enzymes they already know how to make, and maybe, someday, start re-searching some new ones.

"It's not the greatest alternative," says team member Ulla Wohlenberger, "but it's all we have right now. It will be a very little company that will have no place for basic biosensor research in the early years."

Another new company entering the competitive world is the Berlin-based FZB Biotechnik GmbH, a year-old East Berlin company that specializes in optimized fermentation processes, enzymes and microbial cultures. Converted from a 500-person former government research centre to a much smaller private company last year, FZB Bitotechnik is backed by Treuhand funding and the technical expertise of 170 biotech specialists.

Six other new eastern German biotechnology companies will also make their debut at the Biotechnica exposition, displaying their wares together in a joint stand with commercial arms of some 12 eastern German universities and research institutes. This will be their first opportunity of see how their fledgling marketing skills measure up to the established biotechnology powerhouses of the West. It may, as such, be a sobering experience.

"The main problem is that before, they only had to consider the technical part of their research, not the economic," says Karl Schügerl, a biotechnology expert at the University of Hanover.

"They had no problem selling what they had to the East in the controlled market. Now, of course, it's all different." Come October they will find out just how different that is.

\section{French scandal}

London

Two former officials of the Institut de France are in jail awaiting trial for corruption as directors of the powerful research and analysis body prepare to reorganize its administration to avoid further such scandals. Stemming from an investigation in the spring by the Cours des Comptes government auditing agency, a total of four current and former institute employees have so far been charged with offences ranging from embezzlement to receiving stolen goods.

One of the officials, former technical adviser Frédérico Gérard, allegedly coowned a holding company for a security company that was given an institute contract without proper public competition. The Cours des Compte investigation also found "incredible" mismanagement at the institute, which includes the Academie Française and the academy of science, prompting promises of a complete management overhaul.

C.A.

\section{Australian brain drain London}

Australian scientists and academics are leaving the country at twice the rate of four years ago, according to a new survey by the Australian Bureau of Statistics. Last year the country lost 200 scientists, 50 academics and teachers, and 110 doctors, part of an exodus of more than 20,000 professionals and managers. Although Australia has set up a preferred-immigrant programme to attract foreign researchers and other professionals, it provides native academics and scientists with no special incentives to stay in the throes of the country's deepening recession.

\section{$\mathrm{RU}-486$ in UK}

\section{London}

Known in the United Kingdom as Mifegyne and tightly controlled to prevent a black market, the abortion drug RU-486 or whatever this is received its British licence last week and will soon be available on prescription.

Roussel-Uclaf, the drug's French manufacturer, has said that it will supply RU-486 only after it has received a written request from an established hospital or clinic, and every pack will be coded so that its purchaser and prescriber can be tracked. It will also require that all doctors attend a special seminar before they will be allowed to prescribe it.

Private UK abortion clinics said last week that they would offer $\mathrm{RU}-\mathbf{4 8 6}$ as an abortion option at $£ 219$ the same price as a surgical abortion. Three visits will be required: a counselling session, a visit to administer the drug and a final session at which the patient receives the drug prostoglandin, which induces contractions. 